\title{
Negative effects of low developmental temperatures on aphid predation by Orius majusculus (Heteroptera: Anthocoridae)
}

\author{
Friða Helgadóttir ${ }^{\mathrm{a}}$, Søren Toft ${ }^{\mathrm{b}}$, Lene Sigsgaard ${ }^{\mathrm{a}, *}$ \\ ${ }^{a}$ Department of Plant and Environmental Sciences, University of Copenhagen, Thorvaldsensvej 40, DK-1871 Frederiksberg C, Denmark \\ b Department of Bioscience, Aarhus University, Ny Munkegade 116, DK-8000 Aarhus C, Denmark
}

\section{G R A P H I C A L A B S T R A C T}

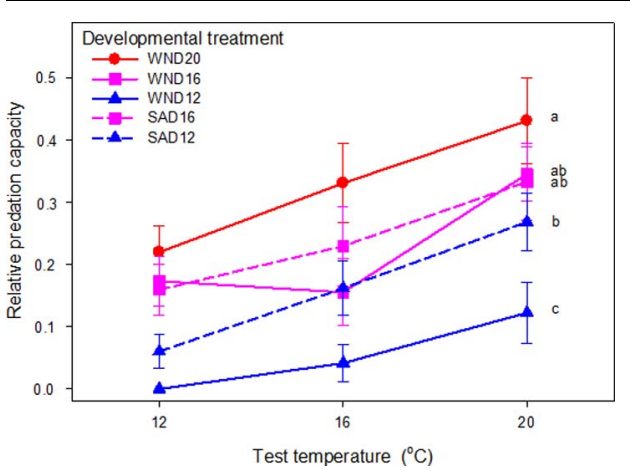

\section{A R T I C L E I N F O}

\section{Keywords:}

Acclimation

Biological control

Dysaphis plantaginea

Predation capacity

\begin{abstract}
A B S T R A C T
Biological control agents (BCA) are often mass reared at conditions very different from those at which they have to provide their service, especially if they are to be used under field conditions. It has been suggested that biocontrol efficiency might be enhanced by acclimating the BCA under near-field conditions for some time before release (beneficial acclimation hypothesis), and some studies (e.g. with ladybirds) have supported this idea. We reared Orius majusculus, a commercially available BCA, at three temperatures $\left(12,16\right.$ and $\left.20{ }^{\circ} \mathrm{C}\right)$ throughout the whole development. The predation capacity for rosy apple aphids (Dysaphis plantaginea) of females from each of these treatments was tested at the same temperatures $\left(12,16\right.$ and $\left.20{ }^{\circ} \mathrm{C}\right)$. Additionally, we tested the effects of low temperature treatment only during the last nymphal instar, to examine if shorter treatments would have the same effects. Our results rejected the positive acclimation hypothesis. At all test temperatures predation capacity was highest for females that had developed at $20{ }^{\circ} \mathrm{C}$ and lowest for those that had developed at $12{ }^{\circ} \mathrm{C}$. Thus, development at low temperatures had a detrimental effect on predatory performance (negative acclimation effect) at both high and low temperatures, and the effect was larger the longer the treatment. Mortality of the nymphs was also increased at lower temperatures. Thus, no enhanced biocontrol efficiency or production benefits were gained from low temperature treatment of $O$. majusculus, neither as full developmental treatment nor as a short term treatment.
\end{abstract}

\footnotetext{
* Corresponding author.

E-mail address: les@plen.ku.dk (L. Sigsgaard).
} 


\section{Introduction}

Temperature is an important factor influencing development, survival and feeding activity of insects (Angilletta, 2009). Biological control agents (BCAs) are produced in a standardized manner, under conditions optimal for reproduction, survival and development (Bigler, 1994). This ensures a rapid and efficient production. However, these conditions may differ drastically from conditions in outdoor cropping systems and therefore may affect the service provided by the biological control agents (Bigler, 1994; Sørensen et al., 2013). To improve their performance, especially in outdoor cropping systems, the theory of thermal acclimation may be applied (Chidawanyika and Terblanche, 2011; Hoffmann, 1995; Prasad et al., 1999; Sørensen et al., 2013; Terblanche 2014). Acclimation is a reversible, non-genetic change in the phenotype, induced by specific environmental conditions (Bennett and Lenski, 1997). An organism acclimated to a particular environment may have a performance advantage over an organism which has not had the opportunity to acclimatize to that environment; this is termed beneficial acclimation (Leroi et al., 1994). The ladybird Adalia bipunctata L. showed improved predation of aphids at temperatures which they were reared at (Sørensen et al., 2013). The codling moth, Cydia pomonella L. was more likely to initiate flight at low temperatures to which they were acclimated (Chidawanyika and Terblanche, 2011). Acclimation at low temperatures may come at a cost of performance at higher temperatures (Chidawanyika and Terblanche, 2011; Kristensen et al., 2008; Sørensen et al., 2013). However, costs of performance at high temperatures can be considered a minor drawback or even irrelevant in some bio-control situations, e.g. in early spring. Several empirical tests have refuted the "beneficial acclimation" hypothesis, however; these results therefore have led to formulation of alternative hypotheses see (Angilletta, 2009; Esterhuizen, 2014; Scharf et al., 2015). The "optimal acclimation" hypothesis (Cohet and David, 1978; Terblanche and Kleynhans, 2009) will be supported if the animals that have developed at the optimal temperature perform best at all subsequent test temperatures (both higher and lower). The "hotter is better" hypothesis posits that high but sublethal acclimation temperature will lead to the best performance (Angilletta et al., 2009). The "colder is better"-"bigger is better" hypothesis (Zamudio et al., 1995) points out that larger females produced at cooler temperatures will have higher fecundity and require more food. All acclimation effects are supposed to have costs on some fitness related parameter (Hoffmann, 1995). Detrimental effects may result from non-optimal temperature treatments if these costs are larger than the beneficial acclimation effects, or if the non-optimal temperature treatments create non-reversible damage effects ("detrimental acclimation" hypothesis) (Loeschcke and Hoffmann, 2002).

The aim of the study was to investigate if thermal acclimation to low temperatures can be applied to increase the predatory efficiency of Orius majusculus (Reuter) (Heteroptera: Anthocoridae), a predatory bug of aphids. The species is native in Danish nature (Skipper and Tolsgaard, 2013). It is also commercially available, therefore it is a potential candidate as BCA for inundative and inoculative biological control strategies in apple orchards to reduce the population growth of rosy apple aphids in early spring (Arnoudov et al., 2013; Wyss et al., 1999) supplementing the naturally occurring early predators. This will depend on the predators' ability to perform at spring temperatures which will often be considerably lower than the temperature it is typically mass-reared at (Alauzet et al., 1992; Blümel, 1996). To test the potential for using $O$. majusculus in spring, the ability of the predatory bug, previously reared at 12,16 and $20^{\circ} \mathrm{C}$, to consume aphids at 12,16 and $20^{\circ} \mathrm{C}$, was investigated. We also wanted to test whether a short treatment period (only last nymphal instar) would have the same effect as treatment covering the full nymphal development; if confirmed, a laborious and costly procedure could be reduced. We discuss our results in relation to the various acclimation hypotheses outlined above, and give recommendations regarding production and handling of $O$. majusculus for use in biocontrol situations.

\section{Materials and methods}

O. majusculus eggs were obtained from a cohort mass-reared at $23.3 \pm 1{ }^{\circ} \mathrm{C}$ by EWH BioProduction ApS, Denmark. They were received on the bean pods used by the females as oviposition material. The eggs were of the same age, being laid within $24 \mathrm{~h}$. Bean pods were left to hatch in separate plastic cups at $20{ }^{\circ} \mathrm{C}$ and a photoperiod of 16:8 L:D and checked daily. Newly hatched nymphs were removed with a moist paintbrush and placed individually in $30 \mathrm{ml}$ cups (height: $4 \mathrm{~cm}$, diameter: $3.5 \mathrm{~cm}$ ) provided with food and water in an Eppendorf tube plugged by cotton. They were randomly assigned to the different rearing treatments (see below), except that nymphs from the same bean pod were distributed evenly to all treatments as they might originate from the same female.

\subsection{Experimental treatments}

Two developmental regimes were used, i.e. whole nymphal development (WND) and subadult development (SAD). In the WND treatment, the nymphs were reared from the beginning of 1 st instar to emergence of adults at temperatures 12,16 or $20^{\circ} \mathrm{C}$ (named WND12, WND16 and WND20; for sample sizes, see Table 2). In the SAD treatments, the nymphs were reared at $20^{\circ} \mathrm{C}$ until emergence of the 5 th instar, and then placed at temperatures 12 or $16{ }^{\circ} \mathrm{C}$ until they moulted to adulthood (named SAD12 and SAD16; Table 2). In the following, the five treatments (WND20, WND16, WND12, SAD16 and SAD12) are termed "developmental treatments", while "developmental temperatures" refer to development at 12,16 and $20^{\circ} \mathrm{C}$, respectively. The temperature of $12{ }^{\circ} \mathrm{C}$ was chosen as the lowest temperature, since during May 2014 in Denmark average temperature (day and night) was $11.7^{\circ} \mathrm{C}$ assessed at $2 \mathrm{~m}$ height (Cappelon, 2016). The highest temperature chosen was $20^{\circ} \mathrm{C}$ as that temperature is found outdoors in spring on sunny days and/or in protected microhabitats; it is also close to the range of optimal rearing temperatures reported for $O$. majusculus, i.e. minimal development time and mortality, and maximal fecundity found in the range of 22 and $25^{\circ} \mathrm{C}$ (Alauzet et al., 1992). Throughout their whole development, nymphs had ad libitum access to Ephestia kuehniella eggs and water. At all temperatures the climate chambers were set at 16:8 L:D photoperiod. Developmental time (assessed by nymphal stage characteristics and presence of exuviae) and mortality were checked daily. Nymphs that died before reaching the adult stage were not included in the developmental calculations. Due to difficulties of finding exuviae of the early instars, data for the development and mortality of the first three instars were pooled. Once the adult stage was reached, individuals were sexed (Fischer et al., 1992) and a random selection of females from each treatment (or all available if they were fewer than 15) was used for the predation capacity tests. The remaining females and males were frozen $\left(-20^{\circ} \mathrm{C}\right)$ for later measurements of adult dry mass.

\subsection{Predation capacity}

Predation capacity tests were performed with $24 \mathrm{~h}$ old, unmated females from each treatment group at 12,16 and $20^{\circ} \mathrm{C}$. As the developmental treatments were all started concurrently but developmental time varied, the predation tests were performed over an extended period as the animals matured. Rosy apple aphids, Dysaphis plantaginea Passerini (Hemiptera: Aphididae), collected from apple trees and reared in the laboratory on plantain (Plantago lanceolata L) at room temperature (approximately $20^{\circ} \mathrm{C}$ ) and 16:8 L:D photoperiod, were used as test prey. The females were starved for $24 \mathrm{~h}$ prior to the tests but with access to water. The tests took place in $30 \mathrm{~mL}$ cups with a layer of water agar on the bottom. An excised leaf disc of plantain, approximately $2 \mathrm{~cm}$ long, was placed vertically into the agar. Ten aphids, 3rd and 4th 
instars in equal amounts (an excessive food supply), were added to the plantain leaf and allowed approximately $2 \mathrm{~h}$ to settle before $\mathrm{O} . \mathrm{ma}$ jusculus was introduced. They were allowed $24 \mathrm{~h}$ to feed and then they were removed. Each female bug was only used once. The short test period $(24 \mathrm{~h})$ means that hardly any acclimation to the test temperature is likely to have occurred. The number of live aphids, dead aphids with sign of feeding, as well as dead aphids without any signs of feeding was registered. Mortality of the aphids during $24 \mathrm{~h}$ at the experimental conditions but without the predatory bugs was also tested ( $n=5$ at 12, 16 and $20^{\circ} \mathrm{C}$, respectively) and found to be zero at all temperatures. Therefore it was assumed that the aphids found dead without any clear sign of feeding had been killed by the predator, either by piercing without subsequent feeding or with minimal feeding. Consequently, the numbers of aphids eaten and the numbers of aphids dead without clear sign of feeding were pooled as total number of aphids killed. This is sometimes referred to as voracity (Butler and O'Neil, 2008). However, in this study the total number of aphids killed by the predator will be referred to as predation capacity (as in Bonte et al. (2015)).

\subsection{Adult body mass and lipid extraction}

Size was measured as adult dry body mass (as in Sørensen et al., 2013; Zamudio et al., 1995). Males and females from the different treatments were measured on Mettler Toledo (MT5) Micro balance. Lipid extraction was performed on the females of the whole nymphal development treatments, which had been tested for predation at the same temperatures at which they had been reared, i.e. whole nymphal development at 12,16 and $20^{\circ} \mathrm{C}$ with predation capacity tests performed at 12,16 and $20^{\circ} \mathrm{C}$, respectively. Lipid extractions were performed on groups of $O$. majusculus (two to three individuals per group) with 5 groups at $12{ }^{\circ} \mathrm{C}$ and 6 groups at $16^{\circ} \mathrm{C}$ and $20^{\circ} \mathrm{C}$. The animals were dried at $60^{\circ} \mathrm{C}$ for $24 \mathrm{~h}$ and weighed. Lipids were then extracted using the Soxhlet method, with petroleum ether as the lipid solvent. Afterwards the samples were dried at $60^{\circ} \mathrm{C}$ for $24 \mathrm{~h}$ and weighed again. The lipid mass was calculated as the difference in dry mass before and after extraction (Jensen et al., 2011).

\subsection{Data analysis}

Analyses were performed using R software or JMP13. Alpha was 0.05 for all hypotheses tested. Predation capacity was analyzed by ANCOVA as proportion of aphids killed as dependent variable with treatment as factor and test temperature as covariate. Prior to analyses, the proportions of aphids killed by the predator were arcsine sqrttransformed to fit ANOVA assumptions. First, the data from WNDtreatments were tested using developmental temperature (3 levels), test temperature (3 levels) and their interaction as factors. Second, the data from all five treatments (WND and SAD) were tested with developmental treatment (5 levels), test temperature (3 levels) and their interaction as factors. Multiple comparisons of least-squares-means (1sm) between different treatments were performed by $t$-tests with adjusted $p$ value (Holm method). The effects of treatments on adult body mass of males and females were analyzed using ANOVA, with lsm comparisons using $t$-test with adjusted $p$-values (Holm method). The durations of each nymphal developmental stage were compared with a KruskalWallis test followed by multiple comparison test (Dunn's procedure for unequal sample size). Following Campbell et al. (1974), the lower developmental threshold (T0) was obtained for each developmental stage and for total nymphal development from a regression between developmental rate and temperature, i.e. where the regression line cuts the $\mathrm{x}$ axis. This was done to see how close our lowest treatment temperature $\left(12{ }^{\circ} \mathrm{C}\right)$ is to the developmental threshold. The corresponding degree days (days) for development were then calculated from the T0-values. The effect of rearing temperature on lipid content (proportion of dry body mass) was revealed by a Kruskal-Wallis test followed by multiple comparison test (Dunn's procedure for unequal sample size). Mortality

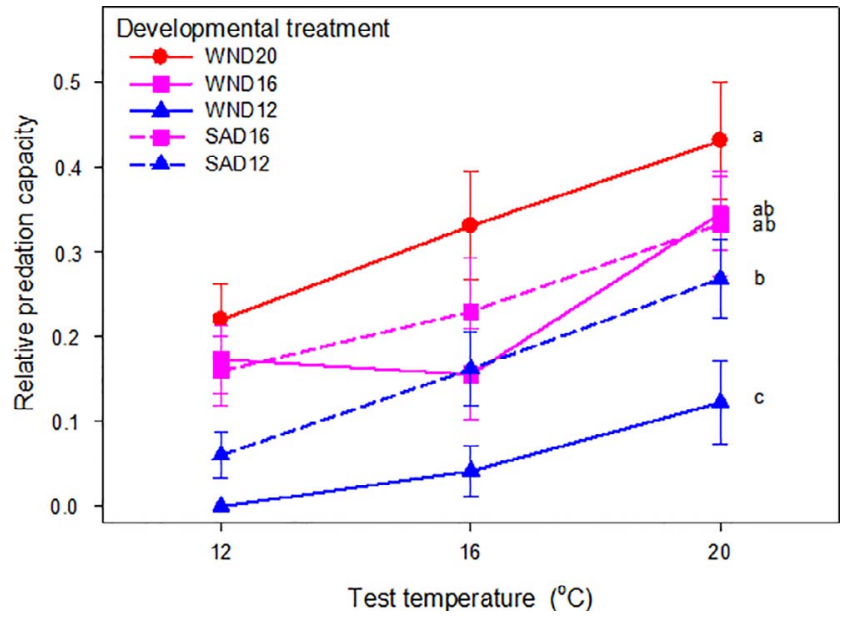

Fig. 1. Relative predation capacity (mean $\pm \mathrm{SE}$ ) at different temperatures of $O$. $m a$ jusculus females from different developmental temperature treatments. Treatment codes: WND20, WND16, WND12 = whole nymphal development at $20,16,12{ }^{\circ} \mathrm{C}$; SAD16, $\mathrm{SAD} 12=$ subadult development at $16,12^{\circ} \mathrm{C}$. Letters to the right: treatments with the same letter are not significantly different (multiple comparisons of ls-means using $t$-test with adjusted $P$-value (Holm method)). Sample sizes for each developmental treatment at test temperatures $12,16,20^{\circ} \mathrm{C}$, respectively: WND20: $N=19,18,17$; WND16: $N=16$, 16, 16; WND12: $N=9,7$, 8; SAD16: $N=16,15,15$; SAD12: $N=14,14,14$.

was calculated as the proportion of the number of individuals dying during a developmental stage to the number entering it. The effects of treatments on sex ratio (\% females) and mortality were analyzed with chi square tests.

\section{Results}

\subsection{Predation capacity}

The relative predation capacity of $O$. majusculus females for the rosy apple aphid increased with test temperature for all five treatment combinations of developmental temperature and treatment length, and at each test temperature it was reduced the lower the temperature at which the animals had developed (Fig. 1). For the WND treatments, both the developmental temperature and the test temperature were highly significant factors, but their interaction was not (Table 1a). Also the five developmental treatments and test temperature were significant, but their interaction not (Table $1 \mathrm{~b}$ ). The non-significant interactions mean that relative predation capacity increased linearly with test temperature and with the same slope for all developmental treatments (Fig. 1). At all test temperatures females from the WND20 treatment showed the highest and the WND12 treatment the lowest

Table 1

Statistical analysis of the predation experiment. The dependent variable was the proportion of aphids killed (arcsine-sqrt-transformed) during $24 \mathrm{~h}$ analyzed in relation to (A) Developmental temperature $\left(12,16,20^{\circ} \mathrm{C}\right)$ and Test temperature $\left(12,16,20^{\circ} \mathrm{C}\right)$ and their interaction (only data from WND treatments included); or analyzed in relation to (B) Developmental treatment (WND20, WND16, WND12, SAD16, SAD12) and Test Temperature $\left(12,16,20^{\circ} \mathrm{C}\right)$ and their interaction. WND: Whole Nymphal Development; SAD: SubAdult Development.

\begin{tabular}{llll}
\hline & d.f & $F$ & $P$ \\
\hline $\begin{array}{l}\text { A. WND-treatments } \\
\text { Developmental temperature }\end{array}$ & 1 & 32.8 & $<0.0001^{*}$ \\
Test temperature & 1 & 17.2 & $<0.0001^{*}$ \\
Dev. temp. " Test temp. & 1 & 0.02 & 0.90 \\
B. WND + SAD-treatments & & & $<0.0001^{*}$ \\
Developmental treatment & 4 & 10.0 & $<0.0001^{*}$ \\
Test temperature & 1 & 34.7 & 0.89 \\
Dev.treatm. " Test temp. & 4 & 0.28 & \\
\hline
\end{tabular}


Table 2

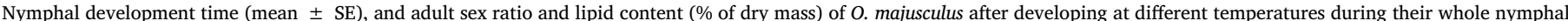

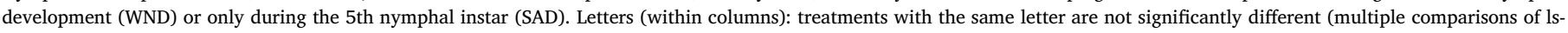
means using $t$-test with adjusted $P$-value (Holm method)).

\begin{tabular}{|c|c|c|c|c|c|c|c|c|}
\hline \multirow[t]{2}{*}{ Treatm. } & \multirow[t]{2}{*}{ Dev. temp. $\left({ }^{\circ} \mathrm{C}\right)$} & \multirow[t]{2}{*}{$N$} & \multicolumn{4}{|c|}{ Development time (days) of nymphal instars } & \multicolumn{2}{|l|}{ Adults } \\
\hline & & & 1st-3rd & 4th & 5th & Total & Sex ratio (\% females) & Lipid content $(\%)^{\dagger}$ \\
\hline WND20 & 20 & 170 & $7.90 \pm 0.05 \mathrm{a}$ & $3.10 \pm 0.04 \mathrm{a}$ & $5.93 \pm 0.07 \mathrm{a}$ & $16.97 \pm 0.12 \mathrm{a}$ & $44.4 \mathrm{a}$ & $25.4 \mathrm{~b}$ \\
\hline WND16 & 16 & 135 & $13.34 \pm 0.09 \mathrm{~b}$ & $5.72 \pm 0.05 b$ & $10.54 \pm 0.08 \mathrm{~b}$ & $29.61 \pm 0.13 c$ & $53.3 \mathrm{a}$ & 29.4 a \\
\hline WND12 & 12 & 69 & $31.82 \pm 0.10 \mathrm{c}$ & $13.97 \pm 0.06 \mathrm{c}$ & $28.20 \pm 0.12 \mathrm{~d}$ & $74.00 \pm 0.19 \mathrm{e}$ & $44.6 \mathrm{a}$ & $26.1 \mathrm{ab}$ \\
\hline SAD16 & $20 / 16^{*}$ & 146 & $7.68 \pm 0.08 \mathrm{a}$ & $3.06 \pm 0.04 \mathrm{a}$ & $10.25 \pm 0.08 \mathrm{~b}$ & $21.00 \pm 0.13 b$ & $43.8 \mathrm{a}$ & \\
\hline SAD12 & $20 / 12$ & 124 & $7.82 \pm 0.09 a$ & $2.90 \pm 0.05 \mathrm{a}$ & $22.25 \pm 0.09 \mathrm{c}$ & $32.98 \pm 0.14 \mathrm{~d}$ & $41.9 \mathrm{a}$ & \\
\hline
\end{tabular}

* Developmental temperature for instar 1-4: $20^{\circ} \mathrm{C}$ (dark shading); for instar 5: 16 or $12{ }^{\circ} \mathrm{C}$, respectively.

Sample sizes for lipid analyses: 5, 6 and 6 groups of 2-3 females.

predation capacity. Both $16{ }^{\circ} \mathrm{C}$ treatments were intermediate (Fig. 1) but together they were significantly different from WND20 (lsm-contrast: WND20 vs. WND16 + SAD16: $F_{1,204}=6.52, \quad P=0.0114$ ). SAD12 lies significantly above WND12. WND12 females had zero predation capacity at $12{ }^{\circ} \mathrm{C}$.

The proportion of killed aphids that was eaten was independent of developmental treatment (3-way ANOVA: $F_{1}=1.05, P=0.31$ ), test temperature $\left(F_{1}=2.84, P=0.094\right)$, and treatment duration (WND vs. SAD) $\left(F_{1}=2.23, P=0.137\right)$. Overall, about half (0.54) of the killed aphids were eaten $(n=151)$.

\subsection{Life-history parameters}

Temperature had a significant effect on the duration of the 1st-3rd instar development as well as for the development of the 4th instar (Kruskal-Wallis test: $\chi^{2}=481.86$ and 546.71 respectively, $\mathrm{df}=4$, $P<0.05$, Table 2). For these stages developmental time was longest for nymphs from WND12 and shortest for WND20 with WND16 intermediate but significantly different from both. Temperature also had a significant effect on the duration of the 5th instar (Kruskal-Wallis test: $\chi^{2}=588.8, \mathrm{df}=4, P<0.05$, Table 2). Instar 5 was shorter in SAD12 than in WND12, while there was no difference in SAD16 and WND16. Total developmental (Kruskal-Wallis test: $\chi 2=607.41$, $\mathrm{df}=4$, $P<0.05$, Table 2) was fastest for WND20 nymphs followed by WND16, and shortest for WND12 nymphs. Total developmental time was significantly shorter for SAD12 than WND12 and also shorter for SAD16 than WND16. The lower developmental thresholds, T0, for the 1st-3rd, 4th, 5th instar and total nymphal development were calculated as 9.3, 9.9, 9.7, and $10.1^{\circ} \mathrm{C}$, respectively, and the corresponding degree day requirements were $82.6,29.8,58.1$, and $178^{\circ}$ days.

There were no significant differences between treatments in sex ratio (Chi-square test: $\chi^{2}=4.2381, \mathrm{df}=4, P>0.05$ ) (Table 2).

Mortality increased with temperature for all developmental stages (1st-3rd nymphal instar: $\chi 2=31.84$, df $=4, P<0.0001$; 4th nymphal instar: $\chi 2=2.98, \mathrm{df}=4, \quad P>0.05 ; 5$ th nymphal instar: $\chi 2=82.93, \mathrm{df}=4, P<0.0001)$ and for total nymphal mortality $(\chi 2=101.07, \mathrm{df}=4, P<0.0001)$. The WND12 treatment had significantly higher mortality than all other groups. Total mortality was higher for WND treatments at 12 and $16^{\circ} \mathrm{C}$ compared to the corresponding SAD treatments, though the differences were only significant at $12{ }^{\circ} \mathrm{C}$ (Table 3 ).

The adult body mass differed significantly between developmental treatments (ANOVA: females $F_{4}=9.13, \quad P<0.0001$; males $F_{4}=17.23, P<0.0001$; Fig. 2). At rearing temperatures 12 and $16{ }^{\circ} \mathrm{C}$, the adult mass of males was higher for SAD than for WND groups. Females showed the same pattern but the difference was only significant at $12{ }^{\circ} \mathrm{C}$. Both sexes had the highest body mass after development at $16{ }^{\circ} \mathrm{C}$ and the lowest after development at $12{ }^{\circ} \mathrm{C}$.

Lipid content of female $O$. majusculus was significantly affected by temperature (Kruskal-Wallis test: $\chi^{2}=6.47, \quad d f=2, \quad P=0.03$,
Table 3

Mortality (\%) during nymphal development of $O$. majusculus after developing at different temperatures during their whole nymphal development (WND) or only during the 5th nymphal instar (SAD). Letters (within columns): treatments with the same letter are not significantly different (multiple comparisons of ls-means using $t$-test with adjusted $P$ value (Holm method)).

\begin{tabular}{lllllll}
\hline \multirow{2}{*}{ Treatm. } & \multirow{2}{*}{ Dev. temp. $\left({ }^{\circ} \mathrm{C}\right)$} & $\mathrm{N}$ & \multicolumn{4}{l}{ Nymphal instars } \\
\cline { 4 - 7 } & & & 1 1st-3rd & 4th & 5 th & Total \\
\hline WND20 & 20 & 197 & $8.1 \mathrm{ab}$ & $2.8 \mathrm{a}$ & $3.4 \mathrm{a}$ & $13.7 \mathrm{a}$ \\
WND16 & 16 & 168 & $13.7 \mathrm{ab}$ & $5.5 \mathrm{a}$ & $1.5 \mathrm{a}$ & $19.6 \mathrm{a}$ \\
WND12 & 12 & 154 & $24.0 \mathrm{c}$ & $6.8 \mathrm{a}$ & $30.3 \mathrm{~b}$ & $50.6 \mathrm{~b}$ \\
SAD16 & $20 / 16^{*}$ & 164 & $4.3 \mathrm{a}$ & $2.5 \mathrm{a}$ & $4.6 \mathrm{a}$ & $10.9 \mathrm{a}$ \\
SAD12 & $20 / 12^{*}$ & 150 & $7.3 \mathrm{ab}$ & $5.8 \mathrm{a}$ & $3.8 \mathrm{a}$ & $16.0 \mathrm{a}$ \\
\hline
\end{tabular}

* Developmental temperature for instar $1-4: 20^{\circ} \mathrm{C}$ (dark shading); for instar 5: 16 or $12{ }^{\circ} \mathrm{C}$, respectively.

Table 2). It was highest in females from WND16 and lowest in females from WND20, with females from WND12 intermediate.

\section{Discussion}

The beneficial acclimation theory is highly debated (Angilletta et al., 2009). While some have found evidence to support it (Chidawanyika and Terblanche, 2011; Sørensen et al., 2013; Thomson et al., 2001), others question or deny it (Gibbs et al., 1998; Gibert et al., 2001; Huey et al., 1999; Smolinský and Gvoždík, 2013). The results from this study do not support the hypothesis of beneficial acclimation, as $O$. majusculus developing at a particular temperature did not improve predation of aphids at those temperatures. On the contrary, developing at low temperatures through whole or part of nymphal development reduced the predation capacity, and the harmful effect was increased the lower the temperature and the longer the treatment. Even the intermediate $16{ }^{\circ} \mathrm{C}$ treatments reduced relative predation capacity significantly.

Also the "cooler is better" hypothesis (Esterhuizen, 2014) can be rejected. Not only did bugs that had developed at the two lower temperatures perform worse than those that had developed at the high temperature, also the assumption behind this hypothesis, i.e. a benefit through increased adult size resulting from low developmental temperature ("bigger is better"), did not hold. Dry body mass and adult lipid content had its maximum at $16{ }^{\circ} \mathrm{C}$. Both parameters are often considered valid indicators of individual body condition (Jacob et al., 1996; Kotiaho, 1999), but in spite of this, the animals that developed at $16{ }^{\circ} \mathrm{C}$ did not show enhanced predation performance at any test temperature. Survival, a superior indicator of environmental conditions, was clearly best at $20^{\circ} \mathrm{C}$. Thus, we have a conflict between indicators of individual body condition and an indicator of environmental quality for the species, with the latter predicting the predatory potential of the predator best. We also exclude the "detrimental acclimation" hypothesis (Loeschcke and Hoffmann, 2002) because reduced predation was 


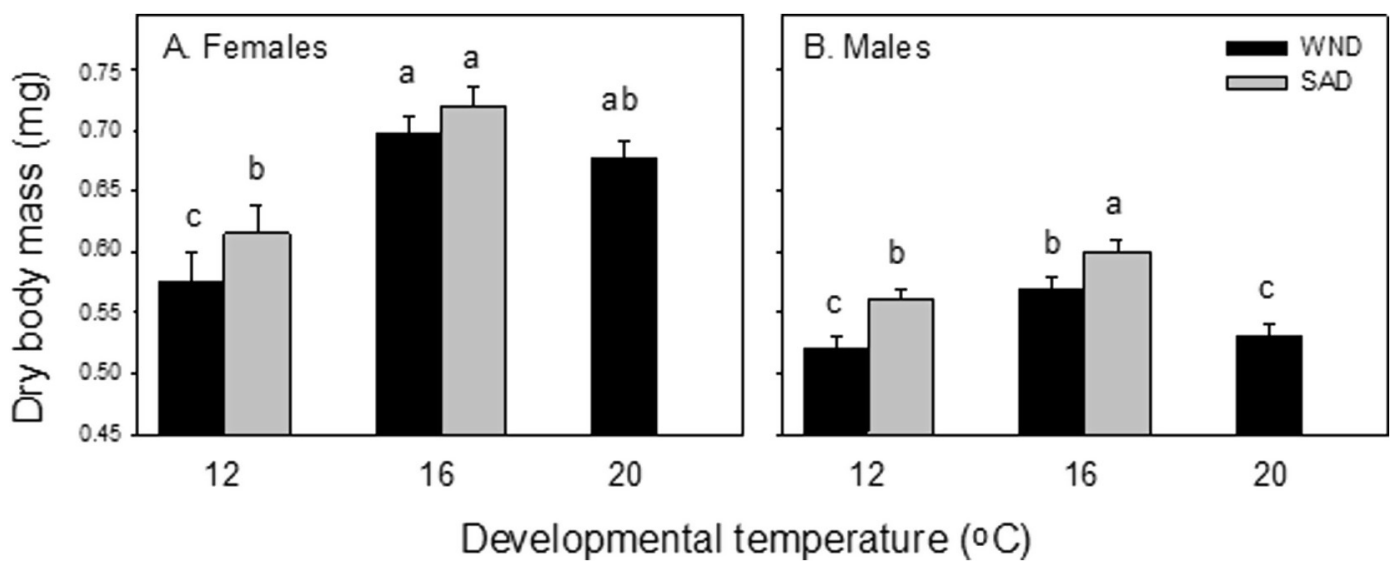

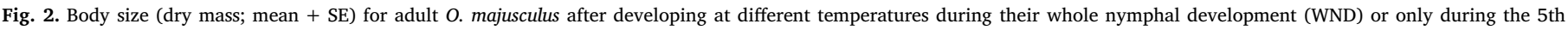

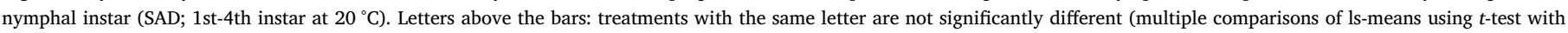
adjusted $P$-value (Holm method)).

apparent already at $16^{\circ} \mathrm{C}$, which is unlikely to have created irreversible damage effects. Two hypotheses, "optimal development" and "hotter is better" may fit our results, but we cannot distinguish them without information for temperatures higher than $20^{\circ} \mathrm{C}$. We should stress that we have tested only for effects of developmental temperature on predation behavior. Possibly, our treatments might have had effects on other performance parameters, e.g. on cold or heat tolerance (cf. Sørensen et al., 2013). The higher lipid content of animals reared at $16^{\circ} \mathrm{C}$ might imply an enhanced starvation tolerance (Arrese and Soulages, 2010).

Our study closely followed the same design as in Sørensen et al. (2013). They worked with the ladybird Adalia bipunctata for which beneficial acclimation was clearly demonstrated. Both predators are commercially available and used as BCA for an overlapping range of pest species, aphids being a common target. Why the beneficial acclimation hypothesis works in one species and not in the other is unclear. Both species occur naturally at temperate climates, e.g. in Denmark, and they have similarities in their life history, e.g. both hibernate as adults. Susceptibility to chilling is due to changes in cell membrane phospholipids causing depolarization of membrane potentials and varies widely among insect species (Overgaard and MacMillan, 2017). The commercial population from which our animals came may have been cultured for more than hundred generations at benign condition including constantly high temperatures $\left(23^{\circ} \mathrm{C}\right)$. Thus, they may have been selected for these conditions and may have lost responses to fluctuating environments. Experiments with animals collected from the field may give an answer to this.

A developmental temperature of $12{ }^{\circ} \mathrm{C}$ was highly detrimental, as it resulted in low survival, small adults and females with lower lipid content compared to individuals that developed at $16^{\circ} \mathrm{C}$. Reduced size and increased mortality at low rearing temperatures has been observed for Drosophila melanogaster and may be due to cold stress (Karan et al., 1998; Kingsolver and Huey, 2008).

This explanation may possibly apply for $O$. majusculus developing at $12{ }^{\circ} \mathrm{C}$. The rearing temperature of $12{ }^{\circ} \mathrm{C}$ was close to the developmental threshold of c. $10^{\circ} \mathrm{C}$ for $O$. majusculus as found in this and other studies (Fischer et al., 1992). However, we did not find a consistent temperature relationship between size and mortality, because body mass was unimodal with maximum at $16{ }^{\circ} \mathrm{C}$ and mortality decreased monotonically with temperature (over the temperature range tested). Thus, mortality was negatively affected at a higher temperature than body size. Female $O$. majusculus developing at $12{ }^{\circ} \mathrm{C}$ and later tested for predation at $12{ }^{\circ} \mathrm{C}$ had zero consumption of aphids. This might indicate that their metabolism was slow and they therefore had reduced consumption after developing at $12{ }^{\circ} \mathrm{C}$. The restricted energy obtained through consumption would be used for basal metabolism, leaving less to build up energy reserves as lipids (Hahn, 2005).

Slightly less than half of the aphids killed showed no visible signs of feeding, indicating that $O$. majusculus is capable of killing more aphids than it can eat. This "surplus killing" behavior has been observed in several arthropods (Fantinou et al., 2008; Lang and Gsödl, 2003; Maupin and Riechert, 2001), including anthocorids (Meyling et al., 2003) and mirids (Fantinou et al., 2008). In a biological control perspective, it is of no importance whether the pest is eaten or simply killed by the biological control agent as long as there is a reduction in the pest population. However, under laboratory conditions the prey density is high and the prey handling time is the most limiting factor, whereas under field conditions the searching behavior of the predator will limit the attack rate more (Bonte et al., 2015). Thus, the surplus killing rate in real biocontrol situations may be much lower.

It should be taken into consideration that this experiment was carried out using rosy apple aphid reared on their alternative host, i.e. plantain. There could potentially be different factors, i.e. textural appearance on aphids feeding on apple trees as well as interaction between host plant and the predator, which could affect the predation efficiency of O. majusculus (Coll et al., 1997; Isenhour and Yeargan, 1981). However, it has been observed that $O$. majusculus is able to feed on the rosy apple aphid on apple trees (Arnoudov et al., 2013). Therefore it can be assumed that predation will occur with inundatively released predatory bugs in apple orchards.

\section{Conclusion: Implications for mass rearing of O. majusculus}

According to our results, there is no reason of changing the mass rearing temperature for $O$. majusculus away from the $23^{\circ} \mathrm{C}$ that is currently used in commercial mass-rearing. Rearing at $20^{\circ} \mathrm{C}$ (and possibly at higher temperatures) gives maximal production efficiency in terms of short production time and high survival, and the bugs give maximal service as BCAs. As we did not test the performance of $O$. majusculus reared at higher temperatures than $20^{\circ} \mathrm{C}$ we cannot state any optimal temperature for mass rearing. However, the effects of low temperatures that we found may have some significance. When packed for shipping from the BCA producer, predators including O. majusculus are often held cool $\left(5-12{ }^{\circ} \mathrm{C}\right)$ for several days during transport, and cooling is an integrated and necessary part of mass production, also used for short term storage (Lenteren et al., 2003). From our results cooling of immatures to $12{ }^{\circ} \mathrm{C}$, even for a few days, may have negative effects on subsequent predation efficiency. According to Rudolf et al. (1993) following storage at $9{ }^{\circ} \mathrm{C}$ for 20 and 50 days, females of $O$. majusculus laid 75 and 34 eggs while the control group laid 122 eggs, also indicating some cold damage on fecundity. For another anthocorid species, cold storage reduced the preoviposition period (Yanik and Ünlü, 2015) 
which is positive in terms of biocontrol. The pros and cons of specific rearing temperatures on predator performance should therefore be tested, probably best in practical situations.

\section{Acknowledgments}

We thank laboratory technician Kristian Hansen, UCPH for assistance with insect rearing and bioassays. This work was funded by the Danish Organic RDD2 programme [grant number 34009-13-0686], coordinated by ICROFS; the Danish Research Council [grant number DFF - 4184-00248]; and the Department of Plant and Environmental Sciences, University of Copenhagen.

\section{References}

Alauzet, C., Dargagnon, D., Hatte, M., 1992. Production d'un hétéroptère prédateur: Orius majusculus [Het.; Anthocoridae]. Entomophaga 249-252.

Angilletta Jr, M.J., Huey, R.B., Frazier, M.R., 2009. Thermodynamic effects on organismal performance: is hotter better? Physiol. Biochem. Zool. 83, 197-206.

Angilletta, M.J., 2009. Thermal Adaptation: A Theoretical and Empirical Synthesis Oxford University Press, UK, Oxford, GBR.

Arnoudov, V., Raikov, S., Davidova, R., Hristov, H., 2013. Predators of rosy apple aphid (Dysaphis plantaginea Pass) (Homoptera: Aphididae) in Bulgarian apple orchards. IV International Symposium "Agrosym 2013".

Arrese, E.L., Soulages, J.L., 2010. Insect fat body: energy, metabolism, and regulation. Annu. Rev. Entomol. 55, 207-225.

Bennett, A.F., Lenski, R.E., 1997. Evolutionary adaption to temperature. VI. Phenotypic acclimation and its evolution in Escherichia cow. Evolution 51, 36-44.

Bigler, F., 1994. Quality control in Trichogramma production. In: Wajneberg, E., Hassans, S.A. (Eds.), Biological Control with Egg Parasitoids. CAB International Oxon, U.K., pp. 93-112.

Blümel, S., 1996. Effect of selected mass-rearing parameters on Orius majusculus (Reuter) and Orius laevigatus (Fieber), Bulletin OILB SROP (France)

Bonte, J., De Hauwere, L., Conlong, D., De Clerca, P., 2015. Predation capacity, development and reproduction of the southern African flower bugs Orius thripoborus and Orius naivashae (Hemiptera: Anthocoridae) on various prey. Biol. Control 86, 52-59.

Butler, C.D., O'Neil, R.J., 2008. Voracity and prey preference of insidious flower bug (Hemiptera: Anthocoridae) for immature stages of soybean aphid (Hemiptera: Aphididae) and soybean thrips (Thysanoptera: Thripidae). Environ. Entomol. 37, 964-972.

Campbell, A., Frazer, B.D., Gilbert, N., Gutierrez, A.P., Mackauer, M., 1974. Temperature requirements of some aphids and their parasites. J. Appl. Ecol. 11, 431-438.

Cappelon, J., 2016. Vejret i Danmark-året 2014. Dansk Meterologisk Institut.

Chidawanyika, F., Terblanche, J.S., 2011. Costs and benefits of thermal acclimation for codling moth, Cydia pomonella (Lepidoptera: Tortricidae): implications for pest control and the sterile insect release programme. Evol. Appl. 4, 534-544.

Cohet, Y., David, J., 1978. Control of adult reproductive potential by preimaginal thermal conditions: a study in Drosophila melanogaster. Oecologia 295-306.

Coll, M., Smith, L.A., Ridgway, R.L., 1997. Effect of plants on the searching efficiency of a generalist predator: the importance of predator-prey spatial association. Entomol. Exp. Appl. 83, 1-10.

Esterhuizen, N., Clusella-Trullas, S., van Daalen, C.E., Schoombie, R.E., Boardman, L., Terblanche, J.S., 2014. Effects of within-generation thermal history on the flight performance of Ceratitis capitata: colder is better. J. Experim. Biol. 3545-3556.

Fantinou, A.A., Perdikis, D.C., Maselou, D.A., Lambropoulos, P.D., 2008. Prey killing without consumption: does Macrolophus pygmaeus show adaptive foraging behaviour? Biol. Control 47, 187-193.

Fischer, S., Linder, C., Freuler, J., 1992. Biologie et utilisation de la punaise Orius majusculus Reuter (Heteroptera, Anthocoridae) dans la lutte contre les thrips Frankliniella occidentalis Perg. et Thrips tabaci Lind., en serre. Revue suisse de viticulture arboriculture horticulture 24, 119-127.

Gibbs, A.G., Louie, A.K., Ayala, J.A., 1998. Effects of temperature on cuticular lipids and water balance in a desert Drosophila: is thermal acclimation beneficial? J. Exp. Biol. 201, 71-80.

Gibert, P., Huey, R.B., Gilchrist, G.W., 2001. Locomotor performance of Drosophila metanogaster: interactions among developmental and adult temperatures, age, and geography. Evolution 55, 205-209.

Hahn, D.A., 2005. Larval nutrition affects lipid storage and growth, but not protein or carbohydrate storage in newly eclosed adults of the grasshopper Schistocerca americana. J. Insect Physiol. 51, 1210-1219.

Hoffmann, A., 1995. Acclimation: increasing survival at a cost. Trends Ecol. Evol. 10, 1-2. Huey, R.B., Berrigan, D., Gilchrist, G.W., Herron, J.C., 1999. Testing of adaptive significansce of acclimation: a strong Inference Approach. Am. Zool. 39, 323-336.

Isenhour, D.J., Yeargan, K.V., 1981. Interactive behavior of Orius insidosus (Hem.: Anthocoridae) and Sericothrips variabilis (Thys.:Thripidae): predator searching strategies and prey escape tactics. Entomophaga 26, 213-219.

Jacob, E.M., Marshall, S.D., Uetz, G.W., 1996. Estimating fitness: a comparison of body condition indices. Oikos 61-67.

Jensen, K., Mayntz, D., Toft, S., Raubenheimer, D., Simpson, S.J., 2011. Nutrient regulation in a predator, the wolf spider Pardosa prativaga. Anim. Behav. 81, 993-999.

Karan, D., Morin, J.P., Moreteau, B., David, J.R., 1998. Body size and developmental temperature in Drosophila melanogaster: analysis of body weight reaction norm. J. Therm. Biol 23, 301-309.

Kingsolver, J.G., Huey, R.B., 2008. Size, temperature, and fitness: three rules. Evol. Ecol. Res. 10, 251-268.

Kotiaho, J.S., 1999. Estimating fitness: comparison of body condition indices revisited. Oikos 399-400.

Kristensen, T.N., Hoffmann, A.A., Overgaard, J., Sørensen, J.G., Hallas, R., Loeschcke, V., 2008. Costs and benefits of cold acclimation in field-released Drosophila. Proc. Natl. Acad. Sci. 105, 216-221.

Lang, A., Gsödl, S., 2003. "Superfluous killing" of aphids: a potentially beneficial behaviour of the predator Poecilus cupreus (L.) (Coleoptera: Carabidae)? Zeitschrift für Pflanzenkrankheiten und Pflanzenschutz / J. Plant Dis. Prot. 110, 583-590.

Lenteren, j.C.V., Hale, A., Klapwijk, J.N., Schelt, J.V., Steinberg, S., 2003. Guidelines for quality control of commercially produced natural enemies. In: In: Lenteren, J.C.v. (Ed.), Quality Control and Production of Biological Control Agents: Theory and Testing Procedures CABI, Wallingford, pp. 265-304.

Leroi, A.M., Bennett, A.F., Lenski, R.E., 1994. Temperature acclimation and competitive fitness: an experimental test of the beneficial acclimation assumption. Proc. Natl. Acad. Sci. 91, 1917-1921.

Loeschcke, V., Hoffmann, A.A., 2002. The detrimental acclimation hypothesis. Physiology $61,243-282$.

Maupin, J.L., Riechert, S.E., 2001. Superfluous killing in spiders: a consequence of adaptation to food-limited environments? Behav. Ecol. 12, 569-576.

Meyling, N.V., Enkegaard, A., Brødsgaard, H., 2003. Two Anthocoris bugs as predators of glasshouse aphids - voracity and prey preference. Entomol. Exp. Appl. 108, 59-70.

Overgaard, J., MacMillan, H.A., 2017. The integrative physiology of insect chill tolerance. Annu. Rev. Physiol. 79, 187-208.

Prasad, R.P., Roitberg, B.D., Henderson, D., 1999. The effect of rearing temperature on flight initiation of Trichogramma sibericum sorkina at ambient temperatures. Biol. Control 16, 291-298.

Rudolf, E., Malausa, J.C., Millot, P., Pralavorio, R., 1993. Influence des basses températures sur les potentialités biologiques d'Orius laevigatus et d'Orius majusculus (Het.: Anthocoridae). Entomophaga 38, 317-325.

Scharf, I., Galkin, N., Halle, S., 2015. Disentangling the consequences of growth temperature and adult acclimation temperature on starvation and thermal tolerance in the red flour beetle. Evol. Biol. 54-62.

Skipper, L., Tolsgaard, S., 2013. Danmarks tæger - en oversigt. I: Danmarks blomstertæger. Apollo Booksellers, Denmark.

Smolinský, R., Gvoždík, L., 2013. Does developmental acclimatization reduce the susceptibility to predation in newt larvae? Biol. J. Linn. Soc. 108, 109-115.

Sørensen, C.H., Toft, S., Kristensen, T.N., 2013. Cold-acclimation increases the predatory efficiency of the aphidophagous coccinellid Adalia bipunctata. Biol. Control 65, 87-94.

Terblanche, J.S., 2014. Physiological performance of field-released insects. Curr. Opin. Insect Sci. 4, 60-66.

Terblanche, J.S., Kleynhans, E., 2009. Phenotypic plasticity of desiccation resistance in Glossina puparia: are there ecotype constraints on acclimation responses? J. Evol. Biol. 1636-1648.

Thomson, L., Robinson, M., Hoffmann, A., 2001. Field and laboratory evidence for acclimation without costs in an egg parasitoid. Funct. Ecol. 15, 217-221.

Wyss, E., Villiger, M., Hemptinne, J.L., Müller-Schärer, H., 1999. Effects of augmentative releases of eggs and larvae of the ladybird beetle, Adalia bipunctata, on the abundance of the rosy apple aphid, Dysaphis plantaginea, in organic apple orchards. Entomol. Exp. Appl. 90, 167-173.

Yanik, E., Ünlü, L., 2015. Storage studies of different stages of Anthocoris minki Dohrn (Hemiptera: Anthocoridae) under low temperatures. Turk. J. Entomol. 277-286.

Zamudio, K.R., Huey, R.B., Crill, W.D., 1995. Bigger isn't always better: body size, developmental and parental temperature and male territorial success in Drosophile melanogaster. Anim. Behav. 49, 671-677. 